\title{
Language and Identity on Facebook: an Online Ethnographic Study of Nicknames, Self-presentation and Religious Identity among a Sub-religious Group in Algeria.
}

\begin{abstract}
:
Early research on nicknames and self-presentation online focused on naming and identity in chatting rooms, gaming platforms and emails. However, recent studies have shifted their interest to naming and identity constructions in more user-generated networks known as Social Networking Sites. Great research has been conducted in the subject in the western world due to its novelty and deep social meaning especially on Facebook. Nicknames have been proved accordingly to be an essential identity marker in SNSs. Although having this great importance, the subject has not received a great attention in the Arab world. In Algeria, most studies focused on code-switching and language contact on Facebook and Twitter in the light of the diglossic situation of the country. The present study investigates naming and identity constructions on Facebook among a sub-religious group in Algeria known as Salafis. Applying the discourse-centered ethnographic research methods, 150 Male Facebook accounts in a friends' network were analyzed and interviews with 30 participants were conducted. The study argues that the use of nicknames was dominant among Algerian Salafis to promote the religious affiliation identity rather than social one on Facebook. Two categories of nicknames emerged: 'implicit nicknames with place of origin reference' and 'explicit with religious affiliation reference'. The characteristics of such identities are described and the implications of these findings are discussed.

Keywords: Facebook; Nicknames and Identity; Salafis; Selfpresentation; Social networking sites
\end{abstract}

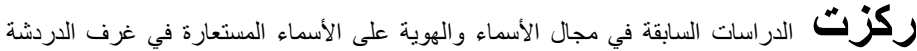

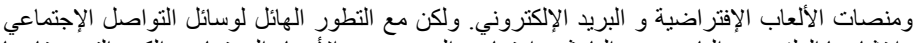

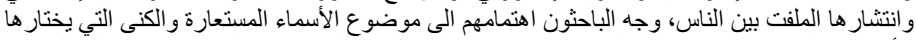

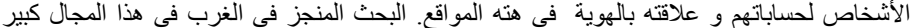

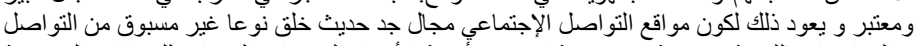

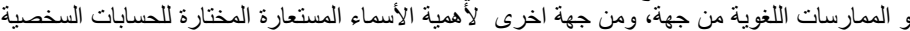

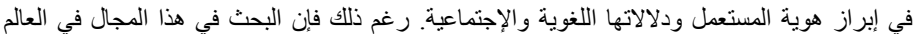

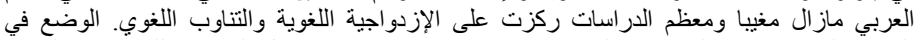

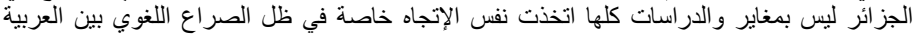

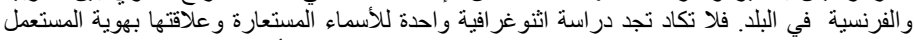

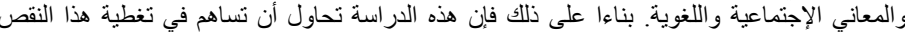

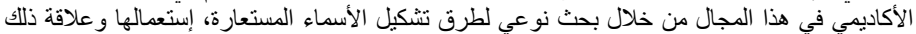

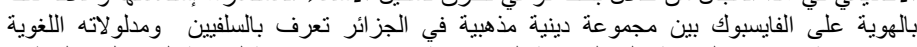

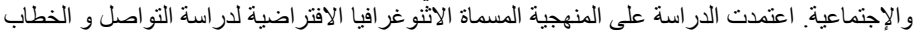

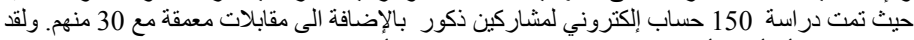

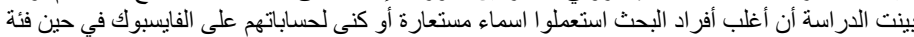

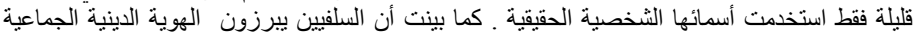

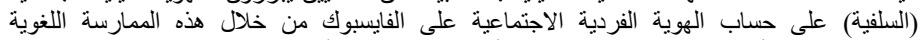

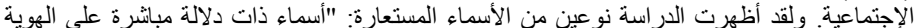

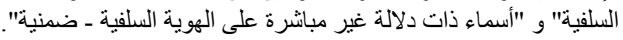

\section{Saoudi Fayçal}

Département des Lettres et Langue Anglaise

Université des Frères Mentouri Constantine

\section{Introduction :}

Man is sociable by nature. We are born to communicate and connect with each other. Communication among humans has always been shaped by the development of communication technologies. Thanks to the astonishing breakthroughs in communication technology and internet in the last decades, Social Networking Sites, such as Facebook, Twitter and Instagram, emerged as the modern face of human communication and became a social phenomenon in a very short time. According to the latest statistics on SNSs, there are over 2.8 billion active social media users worldwide, with about $22 \%$ increase only in the last year (Hustchinson, 2017). Herring (2013) describes SNSs as those novel electronic platforms such as Facebook, Flickr, Twitter 
and YouTube that support social interaction and user-generated content which is "human discourse in the form of text, audio, video, and static images". She adds these spaces are basically of great theoretical and practical interest to scholars of computer-mediated discourse (p. 1).

Being part of such sites as a sociolinguist or researcher in the field of language studies is inspirational as you notice things people would consider ordinary everyday behaviour when it comes to discursive practices. I really had such an experience. I remember I received once a notification on Facebook that one of my friends has changed his Facebook profile name. It was a new creative nickname totally different to his old one. His old one was his real name but the new one became 'أبو الياس محمد القسنطيني' (Abu Illyess Mohamed Al Qassantini). I noticed that he used his real name before, but now he is using a nickname of a specific kind. Moreover, his old name was written in Romanized transcript but the new one is in Arabic transcript. Chatting with him, I figured out that he became affiliated with an Islamic doctrine known as Salafism and the choice of this new nickname was affected by his new identity and it had a deep social meaning. This inspired me to further investigate the phenomenon in an official scientific way. Studying names in Social Networking Sites, and "exploring the motives behind the users' choices and the methods they apply for deciding upon them, not only gives us information on naming customs and habits, it also helps us understand how people - as users, players and participants - see themselves and their place and position in relation to others" (Hagstrom, 2012). Thanks to that, it received a great attention from scholars in the western world in the last twenty years (Bechar-Israeli 1995; Heisler \& Crabill 2006, Hagstrom 2012; Tingstad 2003; Shafie et al. 2012, Georgalou 2015). However, naming and identity on SNSs in the Arab world has been neglected. To my knowledge, it has never been addressed before especially from an ethnographic perspective, and most of the studies in the Arab world focused on code-switching on SNSs, mainly Facebook. In Algeria, the situation is not different and research is still in its infancy. Most of it focuses on language choice and code switching such as Khidher (2014) and Ganaoui (2012) who both studied the situation of Arabic on Facebook, its use and the challenges it is facing. Therefore, the present research represents an exploratory study 
that tries to cover this gap and add some knowledge about the subject to the field.

\section{Literature Review \\ 1. Social Networking}

Social Networking Sites are defined as websites which enable users to (1) create a personal profile within an electronic social platform; (2) build a list of other users with whom to share a connection, the so-called "friendship", and (3) view and browse others profiles - who are not their 'friends'- and not only their list of connections (Boyd \& Ellison, 2007, pp. 211). Mentioning SNSs, the first thing comes to people's mind is Facebook. It is the most popular and highly used SNS in the world which gained this fame in a very short time. Created in 2004 by a Harvard student for intra-campus socializing, Facebook quickly spread to other university campuses and soon became the most popular social networking site among college students in the US (Cassidy, 2006). It was "as a cross between a tool for meeting new people and a platform for networking with people you already know" (Baron 2008, p.84). The origins of Facebook go back to the University of Harvard (Boyd \& Ellison, 2007, pp. 211). It is privately owned by the corporation Facebook, Inc., and was quickly transformed from a "private club within the University of Harvard to a service open to everyone in 2006" (Zhao, 2008). According to Sabatar (2012, p. 81 ), "[o]n this social site, users create a profile through listing personal information and interests, link up with other users and share updates of the information posted on a daily basis". He adds, Facebook enables participants to communicate with others they already know or make new relationships with new people called friends.

Facebook offers many affordances such as a personal Wall (profile), Timeline, News Feed, communication through private or public messages, Instant Messaging (Messenger), photos, videos, links, where friends or users can post their messages and comment on different content. Most research carried out on Facebook analysed the use of this platform from a sociological or pragmatic approach focusing on the sense of community in the relationship between participants while using these SNSs (Sabatar, 2012, p. 82). One of the results of the rise of SNSs such as Facebook is that they have enormously changed the ways we interact and communicate. They do not simply offer an "alternative way of engaging in the same forms of communicative interaction that were 
available prior to their emergence; they also provide a number of notably different communicative dynamics and structures" (Seargent and Tag, 2014, p.2).

Over the last decade, research into SNS discourse has broadened its scope from specific linguistic features to the wider "social and discourse complexities of the socio-technical system" of CMC (Cherny, 1999, p. 298). In what Androutsopoulos (2006) identifies as the "first wave" of language-focused $\mathrm{CMC}$ research, the focus was on structural aspects of language and how they are being affected by communications technologies; they were given priority over other contextual factors. He adds, "the data were often randomly collected and detached from their discursive and social contexts, and generalisations were organised around media-related distinctions such as language of emails, newsgroups, etc". A second wave of language-focused CMC studies shifted attention to the social aspect of discourse such as pragmatics, sociolinguistics, and discourse studies, and emphasises situated language use and linguistic diversity (Androutsopoulos, 2006, p.1).

Social Networking Sites are of great interest to sociolinguistics. According to Seargent and Tag (2014), these sites (and others alike) are novel form of communication, and thus the "study of social language use will want to explore their nature and use". They add, of particular relevance to sociolinguistics "are two fundamental social dynamics at the heart of social network site (SNS) use: the presentation of self (i.e. issues that pivot around notions of identity), and the building and maintenance of networked relationships (i.e. issues relating to concepts of community)". Accordingly, the use of social media as in communication is interesting for two reasons: first, they are different settings to offline situations; and, secondly, because the "novelty and distinctiveness of online interaction bring to the fore many of these contemporary constructivist ideas about the nature of identity" (Seargent and Tag, 2014, p6).

\section{Language and Identity on Social Networking Sites}

Computer-mediated contexts bring to the fore the centrality of language in performing identity, where the typed words on a screen (sometimes in conjunction with other modes such as image and sound) become primary resources for identity work (Page, 2014, pp 46-47). 
According to Goffman, "on social media, both the identity cues that are 'given' - through deliberate and conscious management - and those which are 'given off' - less consciously revealed in interaction - are mediated not through face-to-face co-presence, but primarily through language use" (Goffman, 1959). As Vasquez (2012, p. 68) puts it, "words, language, and discourse continue to serve as key resources in the presentation of self online and in the construction of identities in social media". Boyd's (2001, p. 119) summarises the performance of identities on social media as "writing oneself into being", which reflects the role written language plays in social networking. This is achieved nowadays via visual resources, including typography, orthography and the creative combining of different scripts. Vasquez (2012) points out that researchers tended to explore online identity through member profiles (the sections on social media sites where users are able to provide short demographic and other personal information) (p. 67) where the most important part of a user's profile is the name.

\section{Naming and Identity}

\subsection{Naming and Identities in Off-line World}

A Name is the first thing we acquire the day we are born. It is something essential in humans' life and as Sociologist Richard D. Alford states, ethnographic research has not found yet a society or group where the members have not names (Alford, 1988, p.1). Being such an important social phenomenon was intriguing and attracted the attention of researchers from a variety of disciplines such as onomastics, anthropology, sociopsychology, sociology, human geography and sociolinguistics (Helleland et al., 2012, p.1). Names function as a means for us to form an opinion about who the person, whose name we see or hear, "is". Based on our preconceived notions about other people's names we draw conclusions about their gender, age, ethnicity, nationality, social positions, and maybe even religious beliefs (Hagstrom, 2012, p.83). Within Sociolinguitiscs, the question of names and identities was the core of research. A more recent approach is to elucidate names as identity bearers and identity markers. Shakespeare's famous words "What's in a name?" in the play Romeo and Juliet have been applied widely to refer to the meaning of names, and their validity when it comes to what constitutes the identity of a person (Helleland et al. 2012) 
Most of sociolinguistic research on names is ethnographic and focused on the social functions of names and nicknames and their role in self-presentation and identity construction. In their study of compound surnames among Educated Yuruba married women in Nigeria, Fakuade et al. (2013) found that some of the social factors which are found to be responsible for the use of compound surnames by married women include education, religion and exposure to western culture. They argue further that this practice among educated Yoruba married women is indicative of erosion of this aspect of Yoruba tradition as a result of contact with Islam and the West. Another sociolinguistic study was conducted by Barany et al. (2010) about the Kurdish names in Kurdistan of Iraq and they argued that names are more than just words and have a deep social meaning and are a crucial part of people's identities.

These studies and many more alike have addressed naming and identities in real life or what is referred to as off-line life and all concluded that the choices people make to choose names are not arbitrary but selected on the basis of cultural, ethnic and religious factors to express a specific identity. However, nowadays the notion of naming is getting more and more attention than it has ever had with the rise of social media and SNSs that promotes self-representation and identity construction which is completely different to real life.

\subsection{Names and Identities in Online World}

Hagstrom points out that "questions such as what kinds of names are used, why, and how they are perceived, seem all the more relevant as more and more people spend more and more time in virtual worlds" (2012, p. 85). The first step in the creation of a personal account on SNSs is choosing a name that would identify you in the network. It can be the user's real name, but most of the time, as Hagstrom (2012) states, they are particular names coined for a particular purpose. The latter are what is referred to as nicknames (creative names). She adds, unlike in the off-line world, where names are one of several factors through which we recognise and differentiate people, here it is often the only distinguishing factor (p.87). The variety of nicks provides a rich corpus for psychological, socio-anthropological and sociolinguistic studies. Just as the names and nicknames used by people in real-world society may enlighten us about characteristics and trends in that society, so IRC nicks can shed light on the emergent virtual society. References to collective 
cultural, ethnic, and religious themes in nicknames might indicate that the individual belongs to a certain social group (Beshar-Israeli, 1995).

Haya Bechar-Israeli (1995) was one of the first studies to address the subject of nicknames and identity on IRC (internet relay chat). She found that the nicknames users choose are very important to them. They are an inherent part of their Net- identity, and even of their "real-life" identity. Only rarely did the IRCers in this study use their real names. The largest category was that of nicks related to the self in some way, referring to character traits, physical appearance, the physiological or psychological state of the self, or the person's profession or hobbies. Other works were Tingstad's (2003) study of chatroom nicknames chosen by children in two chat rooms which were categorized into 16 categories such as animals, well-known people and places, Heisler \& Crabill's (2006) study of how different e-mail names are perceived, and Hagstrom (2012) study of the use of nicknames in different virtual platforms such as online gaming and virtual communities.

With the outstanding development of Social Networking Sites in the last decade, researchers have shifted their interest to identities on these sites and devoted some part of their work to naming as it is a crucial part of that phenomenon. Facebook took the greatest attention of scholars and studies were numerous. Examples of such studies include: Shafie et al.'s (2012) study of naming, profile pictures and languages among Malysian university students on Facebook; Zhao's (2008) study of identity construction on Facebook and nonymity among university students in a large Northeastern city in the United States, and Georgalou's (2015) study of identity construction among Greek users of Facebook (naming was one of the aspects investigated in this study). All these studies concluded that nicknames are more important in the construction of identities and self-representation in online settings than in the real world. This is because in real life many other aspects help in marking people's identities such as clothes, physical appearance, etc, however, in the virtual world you can rely only on the user's name to form a first impression and decide what group, ethnicity, class, religion one belongs to.

\section{Focus of the Present Study}

References to collective cultural, ethnic, and religious themes in nicknames might indicate that the individual belongs to a certain social group (Bechar-Israeili, 1995). Accordingly, the aim of this study is to 
investigate the methods of nicknames formation and how they are used in self-presentation and identity construction on Facebook, among a friends' network (group) who are all affiliated to Salafism and what social meaning they hold. Salafis are fundamentalists who believe in a return to the original ways of Islam. The word 'Salafi' comes from the Arabic phrase, 'as-salaf as-saliheen', which refers to the first three generations of Muslims (starting with the Companions of the Prophet), otherwise known as the Pious Predecessors. Modern-day Salafis believe that there is a need to get back to these ideals, instead of following teachings which have become, in their eyes, corrupted in the intervening centuries. The 100-year-old Sunni-based Salafi school of thought aspires to emulate the ways of the Prophet Mohammed. Recognisable from their distinctive long white robes, long beards and flowing head scarf, Salafis are socially and religiously conservative (The week, Jan 2015). Regarding their linguistic ideology, Salafis consider Standard Arabic as holy and supposed to be the only language used by Muslims in all their interactions. The use of Western languages, mainly French and English, is a violation of the Real Islamic principles especially when not really needed. Moreover, they consider it strongly tied to their Salafi identity and a great marker of it. The research applies the online ethnographic methods usually used by researchers in the study of discourse and identity on Facebook, and SNSs in general. Conducting an online ethnographic research imposes adherence to some ethical issues that protects participants' privacy and personal information. Therefore, I gave a great importance to the matter and took permission from participants in each step of the research. None of the participants' Facebook profiles has been consulted without referring to the user and all information used in the study was kept confidential unless the participant allowed me to use it directly.

\section{The Study \\ 1. Participants}

The group under investigation in this study is a friends' network of people who belong to the doctrine known as Salafism on Facebook in Algeria. As any ethnographic research demands accessing the group being studied, I spent a considerable time following the network being studied and its members to gain a deep understanding of their culture. Meanwhile, I built a strong friendship with one of the active members 
who later helped me join the group and gain members trust and cooperation. More importantly, he helped me confirm that all the participants are really Salafis in their real life. The network (group) consists of 205 members. After contacting all members to ask them for taking part of this study, only 150 accepted to be part of the research with the age range between (20 -35 years old). All participants are males and from different states and places within Algeria. The study did not include female users for two reasons: male groups never include female members and vice versa; secondly, I could not access female networks as they do not accept male friends. 30 participants out of 150 were interviewed through video chatting on Messenger (Facebook chatting application).

\section{Method}

As it has been stated before, the aim of the present study is to investigate the use of nicknames on Facebook among Salafis in Algeria and the reasons behind the choices they make. Therefore, the best method for this kind of research is the Discourse-Centred Online Ethnography. This method has been adapted by the majority of researchers working in the field of Facebook discourse and identity such as Georgalou (2015) and Zhao (2008). Data has been collected through the use of online ethno-linguistic methods: participant-observation, documentation, and interviews (Hine 2003, Garcia et al. 2009). Nicknames were collected from participants' profiles (after taking permission from participants due to ethical issues) and then were categorised according to their lexical constituents. Quantitative techniques have also been used to support the study in categorizing the nicknames users chose. Interviews were used to figure out reasons behind the use of nicknames and how they are formed, and also to have a deep understanding of participants' linguistic attitudes and beliefs.

\section{Results and Discussion}

\subsection{Nicknames vs. Real Names}

This section highlights the basic findings of the present study. The results obtained from the investigation of the participants' choice between real names and nicknames for their Facebook profiles are represented in Table 1 . About $94 \%$ of the nicknames are creative names of the participants' real names, whereas, only $6 \%$ kept their real names as their profiles' names. The table shows that most of the participants of the study prefer to create new names for their Facebook profiles rather than 
using the real names. Another key finding is that all names either nicknames or real names of users were written in Arabic Transcript, i.e. the use of Arabic letters and not the Romanized ones (Latin letters).

\begin{tabular}{|l|l|l|}
\hline $\begin{array}{l}\text { Type of } \\
\text { nicknames }\end{array}$ & Percentage of use & Transcript \\
\hline Nicknames & $94 \%$ & \multirow{2}{*}{ Arabic Transcript } \\
\hline Real names & $6 \%$ & \\
\hline
\end{tabular}

Table1. Types of Nicknames

\subsection{Categories of Nicknames}

The data in this section is related to the categories (kinds) of nicknames the participants use for their Facebook profiles, their characteristics and the mechanisms of their formation. Table 2 represents a detailed categorisation of these nicknames. Data showed there are two main categories or types of nicknames:

a- Nicknames with fatherhood reference/ first name + place of origin reference.

b- Nicknames with fatherhood reference / first name + religious affiliation reference.

Briefly, fatherhood status reference is a word used by participants to express his fatherhood status through the use of the word 'Abu' - ابو which is: 'father of' followed by the name of his elder son. First name refers to the user's name (official name). Place of origin refers to words used by participants to show where they come from (country, town, place of origin). Religious affiliation refers to words used to show the users' belonging to a certain religious group or doctrine which is Salafism in this study.

It is highly important to mention that to use users' nicknames in this section as examples for analysis, I took permission from the users that their names are going to appear in the article with all confidentiality and privacy. The majority refused. Thus, I used only the names of those who agreed to do so.

\begin{tabular}{|l|l|l|}
\hline Nickname category & Male users & Transcript \\
\hline $\begin{array}{l}\text { Fatherhood reference/ first } \\
\text { name + origin }\end{array}$ & $64 \%$ & Arabic Transcript \\
\hline $\begin{array}{l}\text { Fatherhood reference / first } \\
\text { name + religious affiliation }\end{array}$ & $36 \%$ & \\
\hline
\end{tabular}

Table 2. Nicknames Categories 


\section{Nicknames with fatherhood reference/ real name and Origin}

This pattern represents $64 \%$ of the choices and was highly preferred by the users. All the nicknames in this category are in Arabic transcript. There are two options of nicknames that fall in this category: "nicknames with fatherhood reference + origin" and "nicknames with first name + origin" which are explained in detail in the following.

\section{a. Nicknames with ( fatherhood reference + place of origin)}

The constituents of this name are a fatherhood reference word that is followed by the place of origin. This is achieved through using the Fatherhood reference word 'Abu' أبو- (father of) + name of elder child followed by a word that refers to the user's place of origin such as country, town or state. These nicknames were common among married participants. However, in some cases, single participants chose such kinds of names with imaginative son's name. If we take for instance one of the study participants' nickname, "Abu Hadi el Djazairi", (Abu Hadi the Algerian), we can observe in forming this name, the user selected words that reflect his fatherhood status "Abu Hadi" which can be translated as "the father of Hadi (his son's name)", and a second word that reflects his country of origin "El Djazairi" (the Algerian). Although the first part reflects a fatherhood status, single Salafi users also used this kind of nicknames. Figure1. Illustrates how this category of nicknames is formed by Salafi participants.

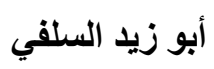

Nickname

Constituents

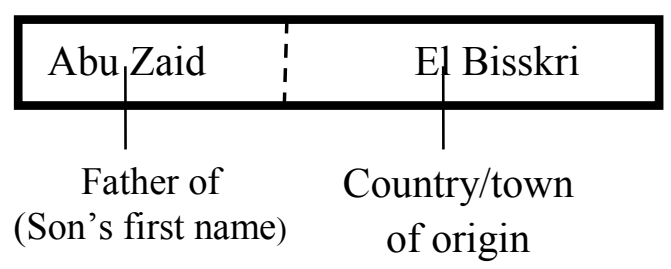

Figure1. Nickname Formation: Category 1-

Option A

b. Nicknames with 'first name + place of origin' 
These nicknames are formed through the use of the user's first name followed by his country or town of origin. For instance, one of the participants' name in this category was: فارس الوهراني - Faris el Wahrani ( Faris the Oranian). In this example, it can be observed that the first part of the name is the user's first name "Faris", followed by an adjective Al Wahrani (the Oranian) that refers to his town of origin which is "Oran". Examples of such nicknames vary according to the participants' places of origin such as "Al Qasantini" (the Constantinian from Constantine), "Al Annabi" (the Anabian from Annaba) and so on. The use of the user's full name instead of the first name is also an option in this kind of nicknames. The mechanism of formation of these nicknames is represented in figure 2 .

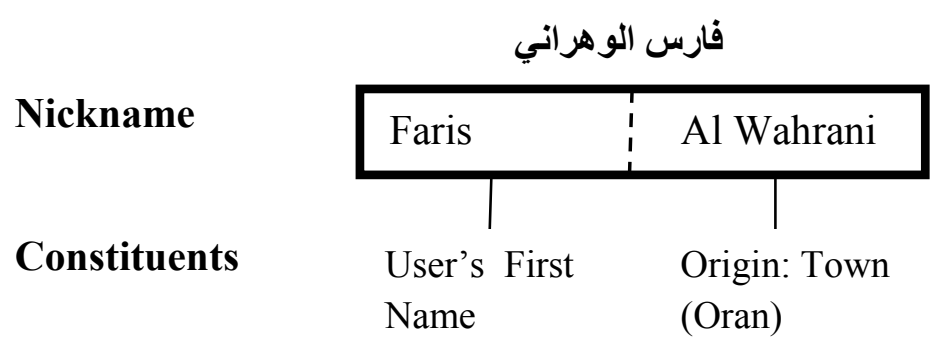

Figure 2. Nickname Formation: Category 1-Option B

2- Nicknames with Fatherhood reference/ user's first name + Salafi Affiliation

The second category of nicknames represents $36 \%$ of the cases. Here also there are two options: either using in the first part of the nickname 'fatherhood reference' or the 'first name of the user'. In forming these nicknames, the participants use words that reflect their fatherhood status or their first name as explained in the following example, followed by words that mark their religious affiliation to the doctrine of Salafism. The following example illustrates the case: "Abu Ahmed EI Salafi" The word that refers to Salafism affiliation in this example is 'al Salafi' and it has other synonyms that all shows affiliation to Salafism and are used the same way among other participants such as 'Al Athari' and 'Al Sunni'. The mechanism of forming such kind of nicknames is represented in figure 2. 


\begin{tabular}{|c|c|c|c|c|}
\hline \multirow{2}{*}{$\begin{array}{l}\text { Nickname } \\
\text { Constituents }\end{array}$} & \multicolumn{2}{|c|}{ ابو زيد السلفي } & \multicolumn{2}{|c|}{ احمد السني } \\
\hline & Abu Zaid & El Salafi & Ahmed & Al Sunni \\
\hline Constituents & $\begin{array}{l}\text { Fatherhood } \\
\text { reference: } \\
\text { 'father of }\end{array}$ & $\begin{array}{l}\text { Religious } \\
\text { affiliation : } \\
\text { Salafism }\end{array}$ & $\begin{array}{l}\text { User's First } \\
\text { name }\end{array}$ & $\begin{array}{l}\text { Relgious } \\
\text { affiliation } \\
\text { salafism }\end{array}$ \\
\hline & & & 1 & \\
\hline
\end{tabular}

Option 2

2

Figure3. Nicknames Formation - Category

\section{Interpretation: Reasons and Implications}

As has been stated before, approaching the research ethnographically is so helpful in reaching better understanding and interpretation of the present study which is achieved mostly through interviews with participants. Therefore, this section represents the interpretation of the data stated in the previous section on the basis of the interviews I conducted with the participants. As far as this study is concerned, interpreting the data is figuring out reasons behind the choices participants made for the nicknames, why such mechanisms of nicknames formation appeared and how does it relate to the notion of self-presentation and identity construction on Facebook. The results expressed above show two major categories of nicknames. Also, one important finding is that all nicknames were written in Arabic transcript and the roman one which is common among users of Facebook in Algeria never appeared in the names. In the following, the interpretation of the data is organised according to the questions or parts of interviews.

\section{Using a Nickname: is it to hide the Real Self?}

Using a nickname rather than the real name for the Facebook profile is mainly interpreted as hiding one's real identity while joining social networks. However, the participants of this study stated that this was not the case. Interviews revealed that the majority of them answered the question related to this point with "no", i.e. the use of 
nicknames was not for the sake of being unknown on Facebook. As one of the interviewees stated, "the creative name I used for my Facebook profile was not because I do not want to be unknown and hide my real identity, but I used this name to express my Salafi Identity which cannot be achieved if I used my real name". This kind of answers was recurrent among the interviewees who strengthened the same idea. Almost all of the interviewees expressed the importance of creating a nickname for their facebook profiles because if they use their real names, they will not be able to express themselves as Salafis. This is due to the fact that although "Algerian real names" may reveal some identity aspects such as gender and ethnicity, they are neutral when it comes to religious identity and affiliation. These findings prove that nicknames play an important role in self-representation on Social Networking Sites (SNSs); they are not just a subscription procedure demanded by Facebook and SNSs to create an account, but a crucial discursive practice in presenting one's self. More broadly, it can be clearly stated accordingly that Facebook offers its users new possibilities for self-representation and identity construction, and enables people to communicate and interact in more freely than in offline life.

The other important part of the interviews touched on the notion of the mechanisms Salafis used to form nicknames for their Facebook profiles what is going to explained in the following section in detail.

\section{Mechanisms of Nicknames Formation and their Implications}

As stated before, there are two main categories of nicknames Salafis chose for their Facebook profiles: nicknames with fatherhood naming/real name + origin, fatherhood/real name+ Salafi affiliation. These nicknames are used by Salafis to represent themselves on Facebook as Salafis. They play the same role in self-representation but function differently. The nicknames that show the origins of the users are considered as indirect references to identity and the nicknames that show Salafi affiliation are direct ones.

The questions I relied on to investigate the mechanisms Salafi Facebookers used to form a nickname were organized according to the choices participants made. Interviewees who chose the first category of 
nicknames which is nicknames with fatherhood reference and place of origin revealed that the purpose behind using these names is not to show personal or national identity (being a father and coming from a certain country or town). However, these nicknames are an imitation of the names of famous scholars and Ulamah of Sunnah such as Al Bukhari (from Bukhara- a town in Uzbekistan), Al Albani (From Albania), etc. Therefore, they chose to form their Facebook names to be similar to those names to represent themselves as Salafisa. Accordingly, it can be stated that the use of nicknames on Facebook among Salafis in Algeria was used as a technique to express one's identity and religious affiliation through alignment and membership within a religious group. In fact, the use of nicknames among Salafis reflects the doctrine beliefs of total imitation of Salaf.

The second group of users chose nicknames that directly refer to the user's affiliation to Salafism: category 2 of nicknames. For instance, one among the interviewees in this group replied to the questions of "why did you use this nickname for your Facebook profile, especially this unique word 'Al Salafi'?" with "in addition to my Salafi friends on Facebook, I have also friends who are not Salafis and that is why I chose a nickname that explicitly marks my Salafi identity". All people in this category revealed the utility of explicit nicknames in showing their Salafi identity to people who are not Slafis on Facebook. This cannot be achieved through the nicknames that implicitly refer to Salafi Identity.

It has been proved that Salafis through the use of these nicknames see themselves as Salafis more than anything else related to their identity (ethnicity, class, education, nationality, etc). Salafis use nicknames that promote group identity rather than personal identity. Although the nicknames they used may refer in some of their parts to personal aspects such as being a father, as it has been explained before, the real reason was to show a Salafi identity and not a personal one.

\section{The Use of Arabic Transcript in Nicknames}

The results aforementioned showed that all Salafi participants who take part in this study used names written in Arabic transcript. This ideology is rooted in the Salafi belief. The use of foreign languages and, more specifically, the roman transcript is considered a 
taboo and entails a lost Islamic identity according to the doctrine. All interviewees stated that the use of Arabic transcript for their nicknames on Facebook is one of the doctrine's principals and the use of the Roman one is considered a violation of the group's rules and against the real Salafi identity. One of the interviewee's answer to the question of transcript choice was, "have you ever seen someone from USA using the Arabic transcript for his Facebook profile name?"; he adds, "I consider the use of roman transcript in names a direct sign of a weak Islamic identity". Another answer was, "the use of Arabic transcript in names on Facebook is the first step towards supporting the language amid the challenges it is facing; it is being threatened." In fact, almost all of the answers supported the same idea. This proves that the choice of Arabic transcript in nicknames among Salafis has a deep social meaning as a discursive practice of self-representation and identity construction in addition to the creative nicknames referred to before.

\section{Conclusion}

Findings of the present study revealed that nicknames play an important role in self-representation and identity construction among Salafi Facebook users in Algeria. The types of nicknames Salafis use can mark their identity directly or indirectly depending on the user preferences and purposes on the network. Moreover, the use of Arabic transcript in nicknames is a must and is strongly tied to their Salafi identity. The study also indicates that Salafis promotes group identity (Salafism) to personal identity on Facebook; they do so through the nicknames they choose for their profiles. This qualitative work represents an exploratory study to the online ethnographic research of social media in Algeria. Only one aspect of users' profiles was investigated. However, future research would consider other aspects such as profile pictures, status, commentaries and multimodal practices in the study of language and identity online. Also, the use of both qualitative and quantitative techniques in such studies would help a lot in achieving more accurate and generalized findings in the subject. 


\section{References}

Alford, R.D. (1987). Naming and Identity: a Cross-cultural Study of Personal Naming Practices. New Haven, Connecticut: HRAF Press.

Androutsopoulos, Jannis. (2006). "Introduction: Sociolinguistics and Computer-mediated Communication". Journal of Sociolinguistics. 10(4). $419-438$

Barany, Lazgin et al. "Kurdish Personal Names in Kurdistan of Iraq: A Sociolinguistic Perspective". academia.edu. Retrieved Oct, 2016.

Baron, Naomi S. (2008): Always on: Language in an Online and Mobile World. New York: Oxford University Press.

Bechar-Israeli H. (1995). "From <Bonehead $>$ to $<$ cLoNehEAd $>$ : nicknames, play and identity on Internet Relay Chat". Journal of Computer-Mediated Communication, 1(2). Online. Available HTTP: $<$ http://jcmc.indiana.edu/vol1/issue2/bechar.html $>$ (accessed November 2015).

Boyd, Danah. (2001). "Depth Cues in Virtual Reality and Real World: Understanding Differences in Depth Perception by Studying Shape-fromshading and Motion Parallax.". Undergraduate computer science honours thesis. Brown University.

Boyd, M. Danah and Nicole B. Ellison. (2007). "Social Network Sites: Definition, History, and Scholarship". Journal of computer mediated communication, 13(1). Pages 210-230

Cassidy, J. (2006). "Me media". The New Yorker, (May 15), 50-59. Accessed Sept 2016

Cherny, Lynn.(1999). Conversation and Community: Chat in a Virtual World. Stanford: CSLI Publications 
Fakuad, Gbenga et al. (2013). "The Sociolinguistics of Compound Surnames among some Educated Yoruba Married Women". Language and Society.org. 3(2). Retrieved 16 Oct 2016.

Ganaoui, Manel. (2012). Al-logha Al-arabia Adet Tawassol ala Mawaqia altwassol al-ijtimai: Dirassa Maydaniya Li Istiemal Al-arabia min Taref Aldjazairin ala Al-facebook [Arabic as a Communication Tool on Social Networking Sites: a Field Study of Arabic Use among Algerians on Facebook]. Al-moltaqa Al-watani hawla Al-mohtawa Al-raqmi bi Alarabia: Al-nacher Al-iliktroni [National Symposium on Digital Content in Arabic: Electronic Publishing]. 24-12-2012. Al-majlis Al-aala Li logha Al-arabia fi Al-djazair [Higher Council of Arabic in Algeria]

Garcia, Cora Angela. et al. (2009). "Ethnographic Approaches to the Internet and Computer-Mediated Communication". Journal of Contemporary Ethnography. 38(1): 52-84. Sage Publications.

Georgalou, Mariza. (2015). Constructions of Identity on Facebook: a Discourse-centred Online Ethnographic Study of Greek Users. Pusblished $\mathrm{PhD}$ Dissertation. Lancaster University.

Goffman, E.1990. (1959). The Presentation of Self in Everyday Life. London: Penguin.

Hagstrom, Charlotte. (2012).Naming Me, Naming You: Personal Names, Online Signatures and Cultural Meaning. In Botolv Helleland, ChristianEmil Ore \& Solveig Wikstrøm (eds.). Names and Identities. Oslo Studies in Language. 4 (2): 81-93.

Heisler, J.M. \& S.L. Crabill. (2006). "Who are 'Stinkybug' and 'Packerfan4'? Email Pseudonyms and Participants' Perceptions of Demography, Productivity, and Personality". Journal of Computer-Mediated Communication, Vol.12, no.1 
Helleland, Botolv, et al. (eds). (2012)."Names and Identities". Oslo Studies in Language 4 (2).

Herring, Susan.(2013). Discourse in Web 2.0: Familiar, Reconfigured, and Emergent. In Deborah Tannen and Anna Marie Trester. (eds.). Discourse 2.0: Language and New Media. George Town University Press.

Hine, Christine . (2003).Virtual Ethnography. UK: University of Surrey.

Hutchinson, Andrew . Jan, 2017. "Top Social Network Demographics 2017." socialmedia.com. $\quad$ Retrieved from http://www.socialmediatoday.com/social-networks/top-social-networkdemographics-2017-infographic. March, 2017

Khidher, Mohammed Al-arabi. (2014). Al-tanawà Al-loghawi fi Shabaket AlFacebook Al-tawassoliya wa Atharoho fi Mostwayat Al-logha Al-arabia [The Lingustic Diversity in the Social Networking Site Facebook and its Impact on Arabic Levels]. Majelet Al-momarasset Al-loghawia [Journal of Linguistic Practices]. Al added 29. Al Safahet 157-174.

Page, Ruth. (2014). Hoaxes, Hacking and Humour: Analysing Impersonated Identity on Social Network Sites. In Philip Seargent and Carroline Tagg. (eds.). The Language of Social Media: Identity and Language on the Internet. UK: Palgrave Mac Millan

Pérez-Sabater , Carmen. (2012) "The Linguistics of Social Networking: A Study of Writing Conventions on Facebook". Linguistik Online. 56, 6/12. Retrieved Mars 2014

Seargent, Philip and Carroline Tag. (eds.). (2014). The Language of Social Media: Identity and Community on the Internet.UK: Palgrave Mac Millan.

Shafie, Latisha, et al. (2012). "Constructing Identity through Facebook Profiles: Online Identity and Visual Impression Management of University 
Students in Malysia". Procedia-scoial and behavioural Sciences, 65, 134140.

Tingstad, Vebyorg. (2003). Children's Chat on the Net: a Study of Social Encounters in Two Norwegian Chatrooms. PhD Diss. Norwegian University of Science and Technology.

Vásquez, Camilla. (2014). Usually not one to complain but...': constructing identities in user-generated online reviews. In Philip Seargent and Carroline Tagg. (Eds.). The Language of Social Media: Identity and Language on the Internet. UK: Palgrave Mac Millan

What is Salafism and should we be worried by it? Jan, 2015. Theweek.com.

Dennis Publishing. Retrieved from: http://www.theweek.co.uk/worldnews/6073/what-is-salafism-and-should-we-be-worried-by-it. Nov, 2016

Zhao, Shanyang.(2008). "Identity Construction on Facebook: Digital Empowerment in Anchored Relationships". Computers in Human Behaviours, 24 (5) 1816-1836. 


\section{Appendix}

\section{Romanized Transcript of Arabic Phonemes}

\begin{tabular}{|c|c|c|c|}
\hline Letter & IPA & Letter & $\underline{\text { IPA }}$ \\
\hline$\underline{\varepsilon} \underline{3}$ & $\underline{?}$ & ص & $\underline{\mathbf{S}}$ \\
\hline 1 & $\mathbf{a}:$ & ض & $\underline{d^{\mathrm{f}}}$ \\
\hline ب & $\underline{\mathbf{b}}$ & b & $\underline{\mathbf{t}}$ \\
\hline ت & $\underline{\mathbf{t}}$ & ط & $\underline{\boldsymbol{\partial}^{\mathbf{S}} \sim \underline{\mathbf{Z}}^{\mathrm{S}}}$ \\
\hline$\dot{H}$ & $\underline{\boldsymbol{\theta}}$ & $\varepsilon$ & $\underline{\mathbf{S}}$ \\
\hline ج & $\widehat{\mathbf{d} \mathbf{3}} \sim \mathbf{q} \sim 3$ & $\dot{\varepsilon}$ & $\mathbf{Y}$ \\
\hline$\tau$ & $\underline{\mathbf{h}}$ & ف요 & $\underline{\mathbf{f}}$ \\
\hline$\dot{\tau}$ & $\underline{\mathbf{x}}$ & & $\underline{\mathbf{q}}$ \\
\hline د & $\underline{\mathbf{d}}$ & ك5 & $\underline{\mathbf{k}}$ \\
\hline$\dot{j}$ & $\underline{\underline{\partial}}$ & J & $\underline{\mathbf{I}}$ \\
\hline
\end{tabular}


Saoudi Fayçal

\begin{tabular}{|c|c|c|c|}
\hline J & $\underline{\mathbf{r}}$ & م & $\underline{\mathbf{m}}$ \\
\hline j & $\underline{\mathbf{Z}}$ & ن & $\underline{\mathbf{n}}$ \\
\hline س & $\underline{\mathbf{S}}$ & 0 & $\underline{\mathbf{h}}$ \\
\hline \multirow[t]{2}{*}{ ش } & I & و & $\underline{\mathbf{w}}, \mathbf{u}:$ \\
\hline & & 9 ي & $\mathbf{i}, \mathbf{i}:$ \\
\hline
\end{tabular}

